\title{
Fine mapping of a Phytophthora-resistance gene RpsWY in soybean (Glycine max L.) by high-throughput genome-wide sequencing
}

\author{
Yanbo Cheng ${ }^{1,2} \cdot$ Qibin Ma $^{1,2} \cdot$ Hailong Ren ${ }^{1,2} \cdot$ Qiuju Xia $^{3} \cdot$ Enliang Song ${ }^{1,2} \cdot$ \\ Zhiyuan Tan ${ }^{1,2} \cdot$ Shuxian $\mathrm{Li}^{4} \cdot$ Gengyun Zhang ${ }^{3} \cdot$ Hai Nian ${ }^{1,2}$
}

Received: 10 November 2016 / Accepted: 26 January 2017 / Published online: 28 February 2017

(C) The Author(s) 2017. This article is published with open access at Springerlink.com

\begin{abstract}
Key message Using a combination of phenotypic screening, genetic and statistical analyses, and highthroughput genome-wide sequencing, we have finely mapped a dominant Phytophthora resistance gene in soybean cultivar Wayao.

Abstract Phytophthora root rot (PRR) caused by Phytophthora sojae is one of the most important soil-borne diseases in many soybean-production regions in the world. Identification of resistant gene(s) and incorporating them into elite varieties are an effective way for breeding to prevent soybean from being harmed by this disease. Two soybean populations of $191 \mathrm{~F}_{2}$ individuals and $196 \mathrm{~F}_{7: 8}$ recombinant
\end{abstract}

Communicated by David A Lightfoot.

Y. Cheng and Q. Ma contributed equally to this work.

Electronic supplementary material The online version of this article (doi:10.1007/s00122-017-2869-5) contains supplementary material, which is available to authorized users.

Hai Nian

hnian@scau.edu.cn

1 The State Key Laboratory for Conservation and Utilization of Subtropical Agro-bioresources, South China Agricultural University, Guangzhou 510642, Guangdong, People's Republic of China

2 The Key Laboratory of Plant Molecular Breeding of Guangdong Province, College of Agriculture, South China Agricultural University, Guangzhou 510642, Guangdong, People's Republic of China

3 Beijing Genomics Institute (BGI)-Shenzhen, Shenzhen 518086, People's Republic of China

4 Agricultural Research Service, Crop Genetics Research Unit, United States Department of Agriculture, Stoneville, MS 38776, USA inbred lines (RILs) were developed to map Rps gene by crossing a susceptible cultivar Huachun 2 with the resistant cultivar Wayao. Genetic analysis of the $F_{2}$ population indicated that PRR resistance in Wayao was controlled by a single dominant gene, temporarily named $R p s W Y$, which was mapped on chromosome 3. A high-density genetic linkage bin map was constructed using 3469 recombination bins of the RILs to explore the candidate genes by the high-throughput genome-wide sequencing. The results of genotypic analysis showed that the RpsWY gene was located in bin 401 between 4466230 and 4502773 bp on chromosome 3 through line 71 and 100 of the RILs. Four predicted genes (Glyma03g04350, Glyma03g04360, Glyma03g04370, and Glyma03g04380) were found at the narrowed region of $36.5 \mathrm{~kb}$ in bin 401 . These results suggest that the high-throughput genome-wide resequencing is an effective method to fine map PRR candidate genes.

$\begin{array}{ll}\text { Abbreviations } \\ \text { BSA } & \text { Bulk segregation analysis } \\ \text { CTAB } & \text { Cetyl trimethylammonium bromide } \\ \text { CIM } & \text { Composite interval mapping method } \\ \text { cv. } & \text { Cultivar } \\ \text { LOD } & \text { Log-likelihood } \\ \text { MSG } & \text { Multiplexed shotgun genotyping } \\ \text { PPR } & \text { Phytophthora root rot } \\ \text { P. sojae } & \text { Phytophthora sojae } \\ \text { QTL } & \text { Quantitative trait loci } \\ \text { RIL } & \text { Recombinant inbred line } \\ \text { SLAF-seq } & \text { Specific length amplified fragment sequencing } \\ \text { SNP } & \text { Single nucleotide polymorphism } \\ \text { Taq I } & \text { Thermus aquaticus DNA polymerase I }\end{array}$




\section{Introduction}

Phytophthora root rot (PRR) caused by Phytophthora sojae is a one of the most important soil-borne diseases in many soybean-production regions in the world, which was first noted in America in 1948 (Schmitthenner 1985; Wrather et al. 2001; Tyler 2007). PRR caused global soybean production losses of \$10-20 billion (Tyler 2007). Since PRR was first recorded in Heilongjiang province in 1991 (Shen and $\mathrm{Su}$ 1991), reports on new races of Phytophthora sojae and their virulence diversity have emerged continuously in major production areas of soybean (Zhu et al. 2004; Cui et al. 2010; Zhang et al. 2010; Huang et al. 2016). PRR can reduce soybean yield by $10-40 \%$ or a complete yield loss (Li and Ma 1999; Zhang et al. 2013a), indicating that PRR is a serious disease potential threat to soybean production in China (Huang et al. 2016).

Soybean resistance to $P$. sojae is controlled by two mechanisms, partial or complete resistance genes (Sugimoto et al. 2012). The mechanism of partial resistance involves multiple genes and limits damage to the plant (Schmitthenner 1985; Dorrance et al. 2003). The other mechanism is related to a single dominant gene resistance (Hartwig et al. 1968; Burnham et al. 2003a; Fan et al. 2009; Yao et al. 2010; Yu et al. 2010; Sugimoto et al. 2011; Sun et al. 2011, 2014; Wu et al. 2011b; Zhang et al. 2013b), in which $P$. sojae interacts with Rps genes in a gene-for-gene system preventing disease development in plants (Schmitthenner 1999).

To date, 22 Rps genes/alleles on eight different soybean chromosomes have been identified, among which Rpsl (five alleles Rpsla, Rpslb, Rpslc, Rpsld, and Rpslk), Rps7, Rps9, RpsYu25, RpsYD29, and RpsUN1 and an unnamed Rps gene in soybean Wascshiroge and E00003 were mapped on the short arm of chromosome 3 (Demirbas et al. 2001; Weng et al. 2001; Gao et al. 2005; Fan et al. 2009; Sugimoto et al. 2011; Sun et al. 2011; Wu et al. 2011a; Lin et al. 2013; Zhang et al. 2013b, 2014). Rps2 and RpsUN2 were found on chromosome 16 (Demirbas et al. 2001; Lin et al. 2013). Rps3 (three alleles Rps3a, Rps3b and Rps3c) and RpsSN10 which was linked with $R p s 8$ were on chromosome 13 (Demirbas et al. 2001; Sandhu et al. 2005; Gordon et al. 2006; Yu et al. 2010). In addition, Rps4, Rps5, Rps6, and RpsJS were located on chromosome 18 (Demirbas et al. 2001; Sandhu et al. 2004; Sun et al. 2014a, b), and Rps8, RpsYB30, RpsZS18, RpsSu, Rps10, and Rps11 were located on chromosome 8,19, 2, 10, 17 and 7, respectively (Burnham et al. 2003a; Zhu et al. 2007; Yao et al. 2010; Wu et al. 2011b; Zhang et al. 2013c; Ping et al. 2016).

Partial resistance or field resistance to $P$. sojae is controlled by quantitative trait loci (QTL) and/or several genes. More than 70 QTLs have been found for partial resistance to $P$. sojae in soybean (Burnham et al. 2003b; Weng et al.
2007; Han et al. 2008; Li et al. 2010; Tucker et al. 2010; Wang et al. 2010, 2012a, b; Wu et al. 2011c; Nguyen et al. 2012; Lee et al. 2013a, b, 2014; Sun et al. 2014a, b; Schneider et al. 2016). Fine mapping using RILs constructed with resistant germplasm and susceptible alleles has been broadly used to identify QTLs underlying tolerance to PRR in recent years (Burnham et al. 2003b; Weng et al. 2007; Li et al. 2010; Tucker et al. 2010; Wang et al. 2010, 2012a, b; Wu et al. 2011c; Nguyen et al. 2012; Lee et al. 2013a, b). Some resistant cultivars (Conrad, Hefeng 25, MN0902, PI398841, and etc) were investigated to compare the phenotypes and yield contributions of QTLs for partial resistance to $P$. sojae in soybean (Burnham et al. 2003b; Jia et al. 2008; Li et al. 2010; Lee et al. 2013a). The results from QTLs, gene analysis, association mapping, joint linkage QTL analyses, and genome-wide association mapping indicate that partial resistance to PRR is regulated by a complex QTL-mediated resistance network (Burnham et al. 2003b; Weng et al. 2007; Li et al. 2010; Wang et al. 2010, 2012a, b; Nguyen et al. 2012; Lee et al. 2014; Sun et al. 2014a, b; Schneider et al. 2016).

Recently, single nucleotide polymorphisms (SNPs) have emerged as genetic markers for their high density and relatively even distribution in the plant genomes. With the rapid development of high-throughput sequencing technology, SNP markers have become practical and give good efficiency and accuracy of QTL mapping (Wang et al. 2011; Duan et al. 2013). Some new sequencing technologies for SNP genotyping of soybean genetic map have been developed with the completion of the whole-genome sequencing of soybean cv. Williams 82 (Hyten et al. 2008, 2010; Li et al. 2014; Lin et al. 2014; Qi et al. 2014). A high-density integrated genetic linkage map consisting of 5500 SNP markers for soybean was constructed (Hyten et al. 2008). Li et al. (2014) used specific length amplified fragment sequencing (SLAF-seq) from RILs to construct a highdensity soybean genetic map with 5785 SLAFs. A novel ion transporter gene $G m C H X l$ was identified using the de novo sequencing and germplasm resequencing approaches (Qi et al. 2014). All these techniques contribute greatly to identify major QTLs or genes in soybean.

In addition, the use of recombination bins which presumably capture all recombination events in the population can provide abundant markers based on dense SNPs for detailed genome-wide trait analysis and serve as a new and effective type of genetic markers for QTL analysis. Huang et al. (2009) constructed a dense genetic map using recombination bins as markers for 150 rice (Oryza sativa L.) RILs by the method of whole-genome sequencing for genotyping recombinant populations. Wang et al. (2011) mapped 49 QTLs of rice at high resolution by sequenced-based genotyping using recombinant inbred lines. However, identification of soybean Rps genes using soybean RILs population 
with high-throughput sequencing technology has not been reported.

In this study, we found that the cv. Wayao had broadspectrum resistance and may carry Rps genes or alleles. The objectives of our project were to characterize the inheritance of the Rps gene(s) and fine map the candidate gene(s) in the resistant cv. Wayao.

\section{Materials and methods}

\section{Plant materials}

The soybean cv. Wayao and Huachun2 were obtained from the Guangdong Subcenter of National Center for Soybean Improvement, South China Agricultural University. To determine which Rps gene or Rps gene combination were present in Wayao, we used a differential set of cultivars/genotypes. Each cultivar/genotype carries one known single Rps gene shown as: Harlon (Rpsla), Harosoy13XX (Rpslb), Williams79 (Rpslc), PI103091 (Rps1d), Williams82 (Rps1k), L76-988 (Rps2), L83-570 (Rps3a), PRX146-36 (Rps3b), PRX145-48 (Rps3c), L852352 (Rps4), L85-3059 (Rps5), Harosoy62XX (Rps6), and Harosoy (Rps7). The cv. Williams (rps) and Huachun 2 were used as the susceptible checks to indicate successful inoculation. Forty individual seedlings of each cultivar were also injured using the method of injured hypocotyl inoculation (Sun et al. 2011). All the differential hosts for PRR identification were kindly provided by the National Center for Soybean Improvement, Nanjing Agricultural University.

The mapping populations of $191 \mathrm{~F}_{2}$ individuals and 196 $\mathrm{F}_{7: 8}$ RILs were derived from Huachun 2 ( $\mathrm{P}_{1}$, PRR susceptible to the isolates of Pm14, Pm28, PNJ1, PNJ3, PNJ4, and P6497) $\times$ Wayao $\left(\mathrm{P}_{2}, \mathrm{PRR}\right.$ resistance to the isolates of Pm14, Pm28, PNJ1, and P6497). Two $F_{1}$ seeds from the cross were self-pollinated to produce the population of $\mathrm{F}_{2}$ plants. One $F_{2}$ plant containing 191 seeds was used for $F_{2}$ individual population. The $196 \mathrm{~F}_{7: 8}$ RILs from the other $\mathrm{F}_{2}$ plant were developed with the single seed descent method (Brim 1966).

\section{Preparation of the $P$. sojae isolates and culture medium}

Six P. sojae isolates (Pm14, Pm28, PNJ1, PNJ3, PNJ4, and P6497), which were provided by Prof. Yuanchao Wang and Han Xing at Nanjing Agricultural University (Wu et al. 2011b) and were used in the phenotype test of disease resistance to PPR. The $P$. sojae isolates were preserved on the slant medium after the processes of strain rejuvenation, separation, and purification (Wu et al. 2011b). The Pm14 strain was used to screen the plant resistance of the $F_{2}$ and RILs population of Huachun $2 \times$ Wayao.

The V8 juice-calcium carbonate medium was prepared using V8 vegetable juice (Campbell Soup Company). After $1.2 \mathrm{~g}$ of calcium carbonate was added into $120 \mathrm{ml}$ of V8 vegetable juice, the mixture was centrifuged for $8 \mathrm{~min}$ at $25^{\circ} \mathrm{C}$ in $4000 \mathrm{rpm}$. One hundred millilitre supernatant was taken out and put into a volumetric flask to be a constant volume with ultra-pure water and $15 \mathrm{~g}$ agar to $1 \mathrm{~L}$. The mixture was then autoclaved at $121^{\circ} \mathrm{C}$ for $20 \mathrm{~min}$. Finally, the solid medium was made from the mixture in petri dishes of 9-cm diameter with appropriate thickness of $1.5 \mathrm{~mm}$.

\section{Evaluation of genetic materials for Phytophthora resistance}

For inoculation with $P$. sojae, all the seeds of $\mathrm{F}_{2}$ population were sown and germinated in a 9-cm diameter plastic bucket filled with vermiculite. To test the phenotypes of the $\mathrm{F}_{2}$ population, the isolate $\mathrm{Pm} 14$ (virulence formula is $1 a$, $1 b, 1 c, 1 d, 1 k, 2,3 a, 3 c, 4,5,6,7)$ was used to inoculate the parental cultivars Huachun 2 and Wayao, individual seedlings of $F_{2}$ population using injured hypocotyl inoculation method with slight modification (Sun et al. 2011). Briefly, after sowing 7-day-old seedlings were inoculated, a uniform and thinner wound was cut in soybean cotyledon under section 1-2 $\mathrm{cm}$ using single-sided blade sterilized with the outer flame of alcohol lamp. The active edge of the colony from $P$. sojae isolate Pm14 cultured in the incubator at $25^{\circ} \mathrm{C}$ for 5 days was cut into about $3 \mathrm{~mm}^{2}$ block and then embedded into the wound area with mycelium surface inside. After inoculation, the seedlings were placed in the culture shelf surrounded by plastic film and kept moisture (90\% relative humidity) at $25^{\circ} \mathrm{C}$ for $24 \mathrm{~h}$ with spraying sterilized water, and then transferred to the pure light room at $20-30^{\circ} \mathrm{C}$ with a 14 -h light and 10 -h dark cycle. Reactions of the seedlings were evaluated 5 days after inoculation. Reactions of $F_{2}$ population were recorded as $\mathrm{S}$ (susceptible, seedling dead with brown hypocotyls) or $\mathrm{R}$ (resistant, seeding alive with no expanding lesion).

To test the phenotypes of RILs population, 12 seeds from every line for each replication were sown and germinated in a 9-cm diameter plastic bucket filled with vermiculite with three replications. During the process of seed germination and seedlings growth, the light time was set to $14 \mathrm{~h}$ per day with a photosynthetic active radiation of $80 \mu \mathrm{mol} \mathrm{m} \mathrm{m}^{-2} \mathrm{~s}^{-1}$ and the culturing room temperature of $30^{\circ} \mathrm{C}$, while the dark time was set to $10 \mathrm{~h}$ per day with the culturing room temperature of $24^{\circ} \mathrm{C}$. Ten selected individuals from the 12 seedlings for each replication were then further inoculated with the isolate Pm14. The parental cultivars of Huachun 2 and Wayao, individual seedlings of RILs population were 
evaluated using injured hypocotyl inoculation method (Sun et al. 2011). Reactions of the seedlings were evaluated 5 days after inoculation. Reactions of RILs population were recorded as the percentage of dead seedlings 5 days after inoculation. The RIL families with $70-100 \%$ dead seedlings were considered to be homozygous susceptible (S), while the RIL families with $0-30 \%$ dead seedlings were considered to be resistance $(R)$. One hundred and forty four individual seedlings of Wayao and Huachun2 were used as the resistance and susceptible checks, and forty individual seedlings of Williams were used as the susceptible checks to indicate successful inoculation. All the experiments were performed in a culturing room at the South China Agricultural University.

\section{$F_{2}$ DNA preparation and pooling for bulk segregation analysis}

Leaf samples were taken from the young seedlings of parents and individual plants of the $\mathrm{F}_{2}$ population. PCR was conducted according to Sun et al. (2011). The genomic DNA from each individual plant was extracted using CTAB (cetyl trimethylammonium bromide) method with minor modifications (Allen et al. 2006). Ten selected homozygous-resistant and ten homozygous-susceptible $\mathrm{F}_{2}$ individuals were used to prepare the DNA pooling for bulk segregation analysis (BSA). Resistant or susceptible bulk of DNA was prepared by pooling equal amounts of $1 \mu \mathrm{g}$ DNA from each of the selected resistant or susceptible individuals, respectively (Michelmore et al. 1991). The final concentration of each bulk was adjusted to $30 \mathrm{ng} / \mu \mathrm{l}$ for PCR analysis (Michelmore et al. 1991).

\section{SSR markers and linkage analysis of resistance gene in $\mathbf{F}_{2}$}

A total of 613 SSR markers uniformly covering the 20 soybean chromosomes were obtained from Soybase (http:// soybase.org/) were used to screen DNA polymorphisms among the two parents and resistant and susceptible bulks of DNA. There were 210 SSR markers polymorphic between the two parents. Four SSR markers (Table S1) were polymorphic between resistant and susceptible bulks of DNA (Michelmore et al. 1991). These four polymorphic markers were further used for analyzing the genotypes and the types of the electrophoretic bands of the $\mathrm{F}_{2}$ population. The SSR reaction program and system were carried out by the method of SSR analysis outlined by Sugimoto et al. (2008).

A genetic linkage map of the Rps genes was constructed using the Mapmaker 3.0b software. Chromosomes were determined with a log-likelihood (LOD) threshold of 3.0. The electrophoresis band types of $\mathrm{F}_{2}$ individuals were compared to those of parents based on the results of SSR markers. The bands consistent with those of soybean parent Wayao were marked as A (1), and the bands consistent with those of soybean parent Huachun 2 were marked as B (3), while the heterozygous bands with those of both parents were marked as $\mathrm{H}$ (2). The individual of disease-resistant phenotype was denoted by R (1), while the individual of susceptible phenotype was denoted by $\mathrm{S}(0)$.

\section{Genome-wide sequencing and analysis}

The high-throughput genome-wide sequencing was performed to construct a high-density genetic map for fine mapping using the $196 \mathrm{~F}_{7: 8}$ RIL populations at BGI-Shenzhen. The genomic DNA was extracted from the parents and the RILs plants using the method of CTAB (Duan et al. 2013).

Genome-wide SNP development and genotyping for the RIL population were performed using MSG (multiplexed shotgun genotyping) as proposed by Duan et al. (2013). The pair-end read libraries were prepared with bar-coded adapters designed and modified by the standard Illumina adapter design. $1 \mu \mathrm{l}$ FastDigest Taq I (Thermo scientific Fermentas) was used to digest $1 \mu \mathrm{g}$ genomic DNA of each sample in a $30 \mu \mathrm{l}$ reaction for $10 \mathrm{~min}$ at $65^{\circ} \mathrm{C} .10 \mu \mathrm{mol}$ unique barcode adapters were then transferred into each well for genomic DNA sample. A ligation reaction with T4 DNA ligase (Enzymatics) were hatched for an hour at $22^{\circ} \mathrm{C}$ and followed by a heat inactivation at $65^{\circ} \mathrm{C}$ for $20 \mathrm{~min}$. All the 24 ligation products were collected into one tube for different samples, and then the restriction enzyme was inactived with $2 \mu \mathrm{l}$ chloroform. The 400-600 bp fragments separated on a $2 \%$ agarose gel were purified by a QIAquick Gel Extraction Kit. A 10-cycle PCR of $50 \mu 1$ reaction, including $25 \mu \mathrm{l}$ Phusion Master Mix, $1 \mu \mathrm{l}$ of $10 \mu \mathrm{M}$ common primer and $1 \mu \mathrm{l}$ index primer, was carried out to amplify all the purified products for each sample (Phusion high-fidelity, Finnzymes). The amplified library purified using a QIAquick PCR Purification Kit was sequenced on a Hiseq 2000 instrument after being quantified on Agilent 2100 Bioanalyzer.

SOAPaligner software ( $\mathrm{Li}$ et al. 2009a, b) was used to compare sequencing reads of each individual according to the identification tag sequence with soybean reference genome. The input file for realSFS using SAMtools (Li et al. 2009a, b) was gained after format conversion of the results by SOAP comparison. The information for every site of RIL population was identified by realSFS to obtain the genotype of each individual according to those of Huachun 2 and Wayao soybeans for reference. Then, the exchange sites of each individual were determined to get the bin genotype of each individual by the genotypes of the parents and the population. Finally, the genetic linkage 
fine map was constructed according to the bin genotype of each individual using MSTMap (http://alumni.cs.ucr. edu/ yonghui/mstmap.html) and MapChart softwares (Voorrips 2002).

\section{QTL mapping}

After constructing linkage map, WinQTLCart2.5 was used for QTL analysis. Composite interval mapping (Zeng 1993, 1994) was performed for all traits. A $10 \mathrm{cM}$ window at a walking speed of $1 \mathrm{cM}$ was used in a stepwise forward regression procedure, and 5 markers were used to eliminate inherent background effects among linked multiple QTL. LOD threshold was calculated using 1000 permutations for an experimentalwise error rate of $P=0.05$. When the positions of QTL affecting a trait overlapped among several locations, they were interpreted to be the same QTL if they fell within a range of $10 \mathrm{cM}$. Additive effects and phenotypic variance were estimated by QTL (R2) at the highest peaks shown in WinQTLCart2.5 analyses.

\section{Results}

\section{Phenotype reaction of Wayao to $P$. sojae isolates}

To investigate the pathotype of Wayao and Huachun 2, six isolates of $P$. sojae were used to test the PRR reaction on 16 soybean genetic differentials (Table 1). The inoculation results showed that Huachun 2, Williams, L76-988 and PRX145-48 were susceptible to all six isolates (SSSSSS). It appears that Huachun 2 did not contain disease-resistant genes, or did not contain Rps2 or Rps3c resistance genes. PRX146-36 (RSSSSR) and Wayao (RRRSSR) were PRRresistant cultivars to Pm14 strain, while other cultivars were PRR-susceptible cultivars to Pm14 strain (Table 1). Furthermore, Wayao was also PRR-resistant to Pm28 and PNJ1 strains different from that of PRX146-36. These results suggest that Wayao may contain new Rps genes.

\section{Genetic analysis of resistance to $P$. sojae Pm14}

The PRR resistance cultivar Wayao plants showed no symptoms in response to $P$. sojae $\mathrm{Pm} 14$ after 5-day inoculation, while the susceptible cultivars Huachun 2 and Williams plants showed severe rot at the inoculation site and all the inoculated plants ultimately died. The segregation ratio was investigated using the individual plants of $\mathrm{F}_{2}$ and RILs population derived from the cross of Huachun $2 \times$ Wayao. The $F_{2}$ and RILs fit well with a genotypic Mendelian 3R:1 S ratio and 1R:1S ratio, respectively $\left(X_{3: 1}^{2}=0.21<X_{0.05}^{2}=3.84, P>0.05\right.$; $X_{1: 1}^{2}=0.16<X^{2}{ }_{0.05}=3.84, P>0.05$ ) (Table 2). These results indicate that the resistance gene in Wayao is controlled by a single dominant gene, temporarily designated as $R p s W Y$.

\section{Mapping RpsWY gene with SSR markers}

Bulk-segregant analyses were used to determine the map location of the unknown Rps gene. Four markers (Satt152, Satt631, Satt009, and Sat_084) on chromosome 3 were investigated and showed DNA polymorphic fragments between the DNA pools (Table S1). The results showed
Table 1 Differential reactions of soybean hosts and cultivars to strains of $P$. sojae

\begin{tabular}{llllllll}
\hline Cultivar & Rps & \multicolumn{2}{l}{ Phytophthora sojae strains } & & \\
\cline { 2 - 7 } & & Pm14 & Pm28 & PNJ1 & PNJ3 & PNJ4 & P6497 \\
\hline Harlon & $1 a$ & $\mathrm{~S}$ & $\mathrm{~S}$ & $\mathrm{R}$ & $\mathrm{S}$ & $\mathrm{S}$ & $\mathrm{R}$ \\
Harosoy13XX & $1 b$ & $\mathrm{~S}$ & $\mathrm{~S}$ & $\mathrm{R}$ & $\mathrm{S}$ & $\mathrm{S}$ & $\mathrm{S}$ \\
Williams79 & $1 c$ & $\mathrm{~S}$ & $\mathrm{~S}$ & $\mathrm{R}$ & $\mathrm{S}$ & $\mathrm{S}$ & $\mathrm{R}$ \\
PI103091 & $1 d$ & $\mathrm{~S}$ & $\mathrm{~S}$ & $\mathrm{~S}$ & $\mathrm{~S}$ & $\mathrm{~S}$ & $\mathrm{R}$ \\
Williams82 & $1 k$ & $\mathrm{~S}$ & $\mathrm{~S}$ & $\mathrm{R}$ & $\mathrm{S}$ & $\mathrm{S}$ & $\mathrm{R}$ \\
L76-988 & 2 & $\mathrm{~S}$ & $\mathrm{~S}$ & $\mathrm{~S}$ & $\mathrm{~S}$ & $\mathrm{~S}$ & $\mathrm{~S}$ \\
Chapman & $3 a$ & $\mathrm{~S}$ & $\mathrm{R}$ & $\mathrm{R}$ & $\mathrm{R}$ & $\mathrm{R}$ & $\mathrm{R}$ \\
PRX146-36 & $3 b$ & $\mathrm{R}$ & $\mathrm{S}$ & $\mathrm{S}$ & $\mathrm{S}$ & $\mathrm{S}$ & $\mathrm{R}$ \\
PRX145-48 & $3 c$ & $\mathrm{~S}$ & $\mathrm{~S}$ & $\mathrm{~S}$ & $\mathrm{~S}$ & $\mathrm{~S}$ & $\mathrm{~S}$ \\
L85-2352 & 4 & $\mathrm{~S}$ & $\mathrm{R}$ & $\mathrm{S}$ & $\mathrm{R}$ & $\mathrm{S}$ & $\mathrm{R}$ \\
L85-3059 & 5 & $\mathrm{~S}$ & $\mathrm{~S}$ & $\mathrm{R}$ & $\mathrm{S}$ & $\mathrm{R}$ & $\mathrm{R}$ \\
Harosoy62XX & 6 & $\mathrm{~S}$ & $\mathrm{~S}$ & $\mathrm{~S}$ & $\mathrm{R}$ & $\mathrm{S}$ & $\mathrm{R}$ \\
Harosoy & 7 & $\mathrm{~S}$ & $\mathrm{~S}$ & $\mathrm{~S}$ & $\mathrm{~S}$ & $\mathrm{R}$ & $\mathrm{S}$ \\
Williams & $r p s$ & $\mathrm{~S}$ & $\mathrm{~S}$ & $\mathrm{~S}$ & $\mathrm{~S}$ & $\mathrm{~S}$ & $\mathrm{~S}$ \\
Huachun 2 & & $\mathrm{S}$ & $\mathrm{S}$ & $\mathrm{S}$ & $\mathrm{S}$ & $\mathrm{S}$ & $\mathrm{S}$ \\
Wayao & & $\mathrm{R}$ & $\mathrm{R}$ & $\mathrm{R}$ & $\mathrm{S}$ & $\mathrm{S}$ & $\mathrm{R}$ \\
\hline
\end{tabular}


Table 2 Segregation analysis of resistance to $P$. sojae Pm14 in cross of Huachun $2 \times$ Wayao

\begin{tabular}{|c|c|c|c|c|c|c|}
\hline \multirow[t]{2}{*}{ Cross or parent } & \multicolumn{3}{|c|}{ Total no. of plants/lines } & \multicolumn{3}{|c|}{ Chi squared tests } \\
\hline & Resistance & Segregation & Susceptibility & Expected ratio & $X^{2}$ & $P$ \\
\hline Williams & 0 & 0 & 40 & & & \\
\hline $\mathrm{P}_{1}$ & 0 & 0 & 144 & & & \\
\hline $\mathrm{P}_{2}$ & 144 & 0 & 0 & & & \\
\hline $\mathrm{F}_{2}$ & 146 & 0 & 45 & $3: 1$ & 0.21 & 3.84 \\
\hline $\mathrm{F}_{7: 8}$ & 102 & 0 & 94 & $1: 1$ & 0.16 & 3.84 \\
\hline
\end{tabular}

Fig. 1 Genetic map of RpsWY on chromosome 3 . A total of 210 polymorphic SSR markers were obtained from Soybase (http://soybase.org/). The genetic map was constructed using the $191 \mathrm{~F}_{2}$ population derived from the cross of Huachun $2 \times$ Wayao using the multipoint analysis of Mapmaker $3.0 \mathrm{~b}$ software. A linkage group was established in a threshold of LOD score 12.64. Chr3-N: Chromosome 3 of MLG N

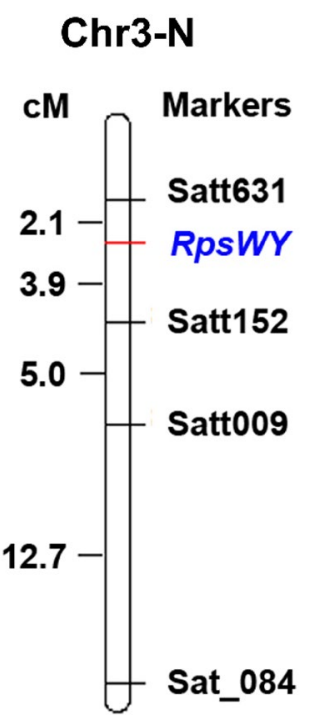

that RpsWY was linked to these four SSR markers and located between Satt631 and Satt152 at a distance of 2.1 and $3.9 \mathrm{cM}$, respectively (Fig. 1).

\section{SNP genotyping}

To investigate the SNP markers, the cultivars Wayao and Huachun 2 were resequenced using the Illumina Hiseq2000 platform with sequencing average depths of $3.85 \times$ and $7.72 \times$, respectively (Table 3 ). The statistical index changed according to the average depth of sequencing between Wayao and Huachun 2. The short reads were mapped back to the genome of soybean Williams 82 using SOAP2 (version 2.20). Approximately, 45.80 and $96.38 \mathrm{Mbp}$ reads, and 4.12 and $8.67 \mathrm{Gbp}$ bases of raw data were obtained. The mapped reads of Huachun 2 and Wayao were 41.34 and 83.75 Mbp, respectively. While the mapped bases of each genotype were 3.72 and $7.54 \mathrm{Gbp}$, respectively, the genome coverage of these two cultivars was 87.50 and $94.63 \%$, respectively (Table 3). A total of 787882 SNPs were identified between the parents using a strict analysis pipeline (Table S2). However, only 70,000 SNPs were found in the RIL population (Table S2).

We resequenced 196 lines of the RILs using 0.2× RADseq (restriction association site DNA sequence) to get the short reads mapped back to the genome of soybean Williams 82 using SOAP2 (version 2.20). All the individuals from 196 lines of RILs were also resequenced using the Illumina Hiseq 2000 platform with an average sequencing depth of $4.88 \times$ and coverage rate of $9.44 \%$ (Table S3). The sequencing data showed that the mapped bases of the RILs were $58.70 \mathrm{Gbp}$ with the average bases of $301.03 \mathrm{Mbp} .145$ soybean lines had more than $200 \mathrm{Mbp}$ bases, and 183 soybean lines had more than 100 Mbp bases. Only line CY-176 had less than $100 \mathrm{Mbp}$ bases (Fig. 2).

Population SNPs were filtered by the sites which were different between the two parents. The SNPs due to noise were removed manually. A total of 70,000 SNPs or 1 SNP per $5 \mathrm{~kb}$ were detected for the RILs. The distribution of SNPs was even throughout the entire genome (Table 4).

\section{Construction of high-density genetic map}

Using the sliding window approach, we chose 15 SNPs for a window as the genetic bin marker distance to identify the genotype for each window and exchange sites for each individual when it slides an SNP every time (Huang et al. 2009; Duan et al. 2013; Wang et al. 2016). Bin information was generated using the genotype for each individual (Huang et al. 2009). After determining the recombination breakpoints for each individual, a total of 3469 bins were detected for the 196 RILs (Table 4). A high-density map
Table 3 Sequencing of Wayao and Huachun 2 soybeans

\begin{tabular}{lllllll}
\hline Cultivars & Total reads (M) & Total base (G) & $\begin{array}{l}\text { Mapped } \\
\text { reads (M) }\end{array}$ & $\begin{array}{l}\text { Mapped } \\
\text { base (G) }\end{array}$ & Coverage (\%) & $\begin{array}{l}\text { Average } \\
\text { depth } \\
(\mathrm{X})\end{array}$ \\
\hline Huachun2 & 45.80 & 4.12 & 41.34 & 3.72 & 87.50 & 3.85 \\
Wayao & 96.38 & 8.67 & 83.75 & 7.54 & 94.63 & 7.72 \\
\hline
\end{tabular}




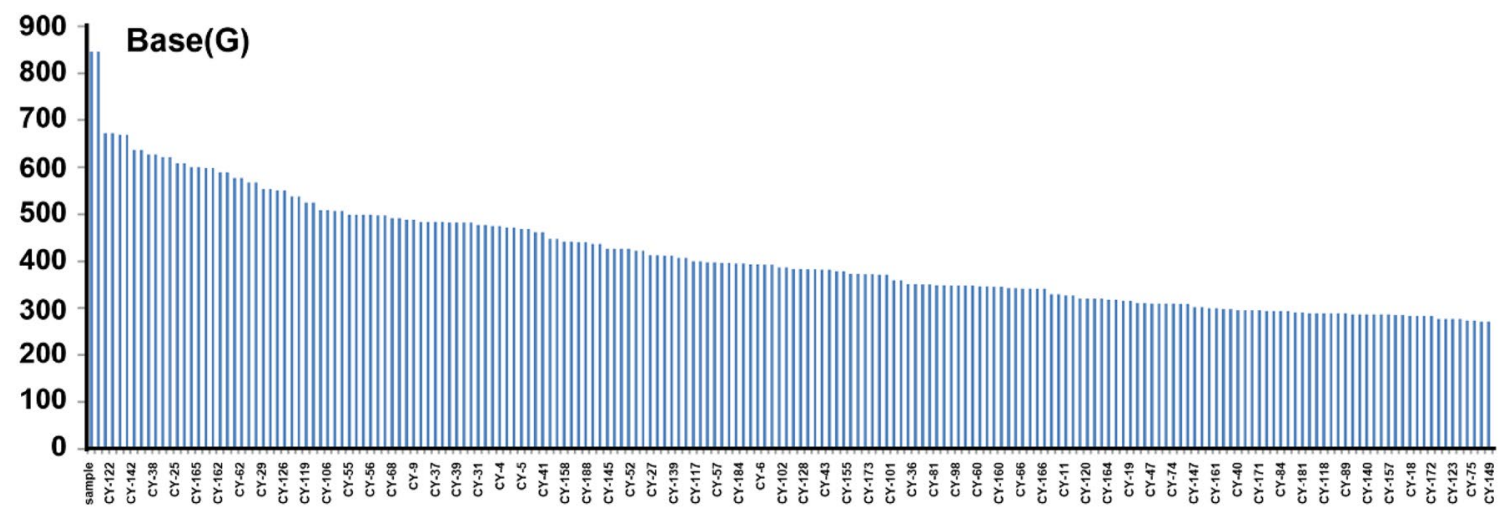

Fig. 2 Sequencing data statistics of each individual of RILs population. One single plant was taken from every line of the $196 \mathrm{~F}_{7: 8}$ RILs population. Horizontal axis shows different lines of RIL population, and vertical coordinate shows total numbers of bases (Mbp)

Table 4 Bin number and Linkage distance of Chromosomes

\begin{tabular}{lcc}
\hline Chromosome & Number of bins & Linkage distance \\
\hline Gm01 & 177 & 262.2 \\
Gm02 & 189 & 264.7 \\
Gm03 & 184 & 209.9 \\
Gm04 & 108 & 182.2 \\
Gm05 & 169 & 240.1 \\
Gm06 & 212 & 238.9 \\
Gm07 & 152 & 190.5 \\
Gm08 & 197 & 252.9 \\
Gm09 & 214 & 234.9 \\
Gm10 & 145 & 211.2 \\
Gm11 & 177 & 209.0 \\
Gm12 & 128 & 174.2 \\
Gm13 & 216 & 250.8 \\
Gm14 & 132 & 184.2 \\
Gm15 & 143 & 176.6 \\
Gm16 & 201 & 235.9 \\
Gm17 & 174 & 182.0 \\
Gm18 & 199 & 263.2 \\
Gm19 & 159 & 173.9 \\
Gm20 & 193 & 206.0 \\
Total & 3469 & 3855.5 \\
\hline & &
\end{tabular}

was constructed using the bins as markers (Fig. 3; Fig. S1, S2).

Using CIM (composite interval mapping method) with WinQTLCart for Rps gene localization, RpsWY gene was amplified at the site of bin 401 on chromosome 3 in the high-density linkage map (Fig. 3). The RpsWY gene was located in the region of 4,466,230-4,502,773 bp through recombinant monoclonal line 71 and line 100 which were resistant to $P$. sojae Pm14 strain (Figs. S3 and S4). Four candidate Rps genes of Glyma03g04350, Glyma03g04360, Glyma03g04370, and Glyma03g04380 were located at
Fig. 3 Genetic map of soybean chromosomes. The virtual point line represents the truncated segment of the chromosome 3. The asterisk indicates the location of bin 401

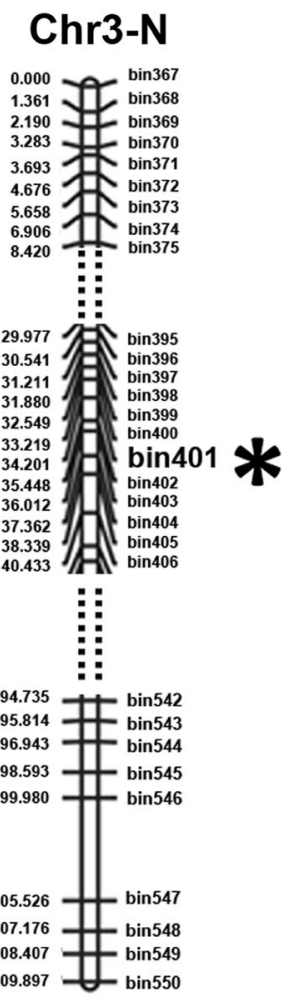

the region (Fig. 4). The results of bioinformatic analysis showed that Glyma03g04350 encodes a predicted pentatricopeptide repeat-containing protein possibly involved in RNA editing (Kotera et al. 2005), Glyma03g04360 encodes a predicted transposase/serine/threonine protein phosphatase, while Glyma03g04370 encodes a predicted non-specific lipid-transfer protein 3-like protein. The above three genes encoding predicted proteins with complete structural domains and larger molecular weights indicate Glyma03g04350, Glyma03g04360, and Glyma03g04370 maybe the potential candidate genes of RpsWY (Fig. 4). A non-specific lipid-transfer protein encoded by 


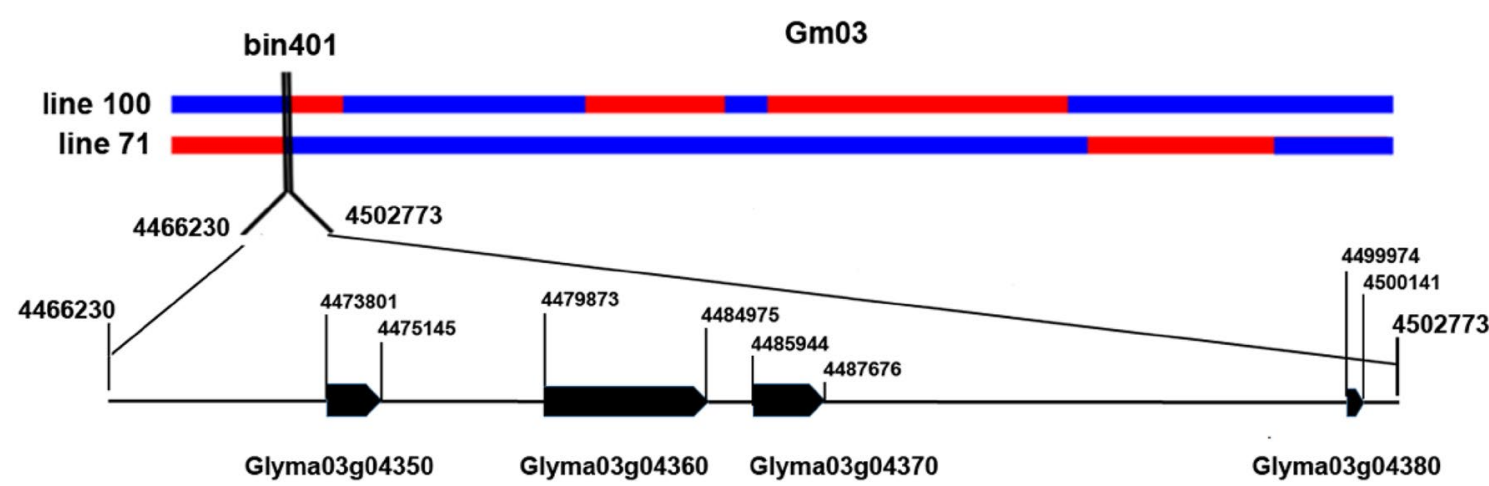

Fig. 4 Fine mapping of RpsWY. Recombinant Line71 and Line100 were from the RILs population. Blue blocks designates Wayao genotype on chromosome 3, and red blocks designates Huachun 2 genotype on chromosome 3. Line71 and Line100 were resistant to P. sojae Pm14. Four candidate Rps genes of Glyma03g04350,

Glyma03g04380 with lower molecular weight and small size protein indicates that Glyma03g04380 may not be the major potential candidate gene of $R p s W Y$ (Fig. 4).

\section{Discussion}

There are large numbers of soybean accessions in China, and many PRR resistance germplasm were identified in the previous study (Lohnes et al. 1996; Kyle et al. 1998; Zhu et al. 2006; Sun et al. 2008; Tang et al. 2010; Xia et al. 2011; Ren et al. 2012; Cheng et al. 2015). In our previous investigation, availability of multiple PRR-resistance accessions, including Wayao in South China had been identified (Cheng et al. 2015). Wayao is a PRR-resistance cultivar to P. sojae Pm14, Pm28, PNJ1 and P6497 (Table 1). It had a broad-specturm resistance to PRR races or isolates.

In the present study, RpsWY is flanked by Satt631 $(2.1 \mathrm{cM})$ and Satt152 $(3.9 \mathrm{cM})$, Satt009 $(5.0 \mathrm{cM})$, Sat_084 $(12.7 \mathrm{cM})$ on chromosome 3 using SSR marker analysis, and mapped to Rps gene rich regions on soybean chromosome 3. The results of SNP markers analysis indicated that $R p s W Y$ gene is located within the interval from 4,466,230 to $4,502,773 \mathrm{bp}(36.5 \mathrm{~kb})$ on chromosome 3 falling in the area of the Rps $1 k$ interval from 4,457,810 to 4,641,921 bp (Gao and Bhattacharyya 2008). Twelve known Rps genes were identified and mapped to chromosome 3 before RpsWY, including five alleles of Rpsl (Bernard et al. 1957; Mueller et al. 1978; Anderson and Buzzell 1992), Rps7 (Weng et al. 2001), Rps9 (Wu et al. 2011a), RpsYu25 (Sun et al. 2011), RpsYD25 (Fan et al. 2009), RpsYD29 (Zhang et al. 2013a), RpsUNl(Lin et al. 2013), a Rps gene in Waseshiroge (Sugimoto et al. 2011) and a Rps gene in soybean E00003 within the Rpslk interval (Zhang et al. 2014). $R p s W Y$ is a distinct gene from the Rpsl alleles, because five
Glyma03g04360, Glyma03g04370, and Glyma03g04380 were located at the region of recombinant bin401. The position information of candidate genes was from the website of soybase: http://soybase.org/. (Color figure online)

differentials carrying Rpsl ( $1 a, 1 b, 1 c, 1 d$, and $l k$ ) were PRR-susceptible to $P$. sojae Pm14 in our current study. The position information below SSR marker Satt152 (Fig.S5) suggests that RpsWY is distinct from RpsUN1, RpsYD29 and Rps7 (Weng et al. 2001; Lin et al. 2013; Zhang et al. 2013a). Otherwise, $R p s 9$ was flanked by Satt152 (10.1 cM) and Satt631 (7.5 cM) (Fig.S5) (Wu et al. 2011a). RpsYu25 is located between $3,338,620$ and $3,465,436$ bp by converting the flanking markers of Satt152 and Sat_186 from the interval 30.1 to $32.8 \mathrm{cM}$ (Fig.S5) (Song et al. 2010; Sun et al. 2011). The locus analysis of SSR markers and sequence interval indicates that $R p s W Y$ is a distinct gene from Rps 9 and RpsYu25. In addition, the Rps gene in Waseshiroge is located between Satt009 and T003044871 and may reside in the nucleotide region between 3,919,203 and 4,486,048 $(567 \mathrm{~kb})$ on chromosome 3 (Sugimoto et al. 2011). The Rps gene in E00003 was located within interval 4,475,877-4,563,799 bp (87.9 kb) on chromosome 3 (Zhang et al. 2014). RpsWY and the Rps gene from Waseshiroge or E00003 may be allelic, but not Rps $1 k$. Therefore, $R p s W Y$ could be a new allele locus or a new gene. To confirm this finding, additional crosses between Wayao and Waseshiroge or E00003 should be made and genetically analyzed. In previous studies, more than 20 Rps genes/ alleles have been mapped and designated to ten loci on four soybean chromosomes (13,18,16, and 3) since Rpsl was identified for the first $P$. sojae resistance genes (Lin et al. 2013; Zhang et al. 2014). However, none of them was finely mapped by using low density genetic maps. Rpsl was one of the Rps genes which has been mapped to chromosome 3 of the USDA-ARS soybean Williams isolines (containing the genes Rj2 Rmd-c Rps2 Ti-a) approximately $2 \mathrm{cM}$ from locus A071-1 by the restriction fragment length polymorphism (Polzin et al. 1994). Two Rpsl-k genes were predicted by the sequence analysis using a shotgun sequencing 
strategy applied in sequencing the BAC contig (Gao et al. 2005). However, more Rps genes were mapped on different chromosomes using $\mathrm{F}_{2}, \mathrm{~F}_{2: 3}$ and/or RIL populations by SSR markers (Demirbas et al. 2001; Weng et al. 2001; Fan et al. 2009; Sugimoto et al. 2011; Sun et al. 2011; Wu et al. 2011a; Lin et al. 2013; Zhang et al. 2013b, c, 2014). In our study, RpsWY was mapped on chromosome 3 with 191 $\mathrm{F}_{2}$ individuals, which was located in the Rps-rich region, by genetic and physical analysis (Fig. S5). The candidate gene of RpsWY was further investigated using the $196 \mathrm{RIL}$ population. Fortunately, we found that $R p s W Y$ was located within interval 4,466,230-4,502,773 bp (36.5 kb) on chromosome 3 covering the sites of four potential candidate genes of RpsWY. Analyzing the overlapping region of line 71 and line 100 indicates that the discovery of recombinant monoclonal line 71 and line 100 was crucial for the fine mapping of the candidate genes (Fig. 4).

All the results suggest that high-throughput genomewide resequencing is an effective method to finely map PRR candidate genes and to help expound their mechanism of disease resistance.

Acknowledgements We thank Yuanchao Wang and Han Xing (Nanjing Agricultural University, Nanjing, PR China) for kindly supplying the P. sojae of Pm14 stain and differential soybean hosts. This work was supported by the National Natural Science Foundation of China (30971814); the China Agricultural Research System (CARS04-PS09); the Science and Technology Projects of Guangdong Province (2011A020102010); the Project of Molecular Design Breeding for Major Economic Crops (2016yfd0101901) and the Research Project of the State Key Laboratory of Agricultural and Biological Resources Protection and Utilization in Subtropics (4100-M13024). Mention of trade names or commercial products in this publication is solely for the purpose of providing specific information and does not imply recommendation or endorsement by the United States Department of Agriculture. USDA is an equal opportunity provider and employer.

\begin{abstract}
Author contribution statement $\mathrm{HR}$ constructed $\mathrm{F}_{2}$ population and carried out statistical and linkage analyses of phenotypic data. ES planted and supplied $\mathrm{F}_{1}$ seeds. QM provided guidance on molecular analysis and marker used. YC developed the RILs population, conducted phenotypic screenings, prepared inoculation, designed the severity rating scale, and contributed to data analysis. SL provided guidance to design the inoculation experiment. QX and GZ analyzed the data of genome-wide sequencing to produce the final linkage and bin map. HN planned the research and supervised the project. QM, YC, SL, ZT, and HN prepared the manuscript.
\end{abstract}

\section{Compliance with ethical standards}

Conflict of interest The authors declare that they have no conflict of interest

Open Access This article is distributed under the terms of the Creative Commons Attribution 4.0 International License (http:// creativecommons.org/licenses/by/4.0/), which permits unrestricted use, distribution, and reproduction in any medium, provided you give appropriate credit to the original author(s) and the source, provide a link to the Creative Commons license, and indicate if changes were made.

\section{References}

Allen GC, Flores-Vergara MA, Krasynanski S, Kumar S, Thompson WF (2006) A modified protocol for rapid DNA isolation from plant tissues using cetyltrimethylammonium bromide. Nat Protoc 1(5):2320-2325

Anderson TR, Buzzell RI (1992) Inheritance and linkage of the Rps7 gene for resistance to Phytophthora rot of soybean. Plant Dis 76:958-959

Bernard RL, Smith PE, Kaufmann MJ, Schmirthenaer AF (1957) Inheritance of resistance to Phytophthora root and stem rot in the soybean. Agron J 49:391

Brim CA (1966) A modified pedigree method of selection in soybeans. Crop Sci 6:220

Burnham KD, Dorrance AE, Francis DM, Fioritto RJ, Martin SKS (2003a) Rps8, a new locus in soybean for resistance to Phytophthora sojae. Crop Sci 43:101-105

Burnham KD, Dorrance AE, VanToai TT, Martin SKS (2003b) Quantitative trait loci for partial resistance to Phytophthora sojae in soybean. Crop Sci 43:1610-1617

Cheng YB, Ma QB, Mu YH, Tan ZY, Wu H, Nian H (2015) Analysis of resistance genes of soybean accessions from South China to Phytophthora root rot. Sci Agric Sin 48(12): 2296-2305

Cui KL, Yin WX, Tang QH, Dong SM, Zheng XB, Zhang ZG, Wang YC (2010) Distribution, pathotypes, and metalaxyl sensitivity of Phytophthora sojae from Heilongjiang and Fujian provinces in China. Plant Dis 94:881-884

Demirbas A, Rector BG, Lohnes DG, Fioritto RJ, Graef GL, Cregan PB, Shoemaker RC, Specht JE (2001) Simple sequence repeat markers linked to the soybean Rps genes for Phytophthora resistance. Crop science 44:1220-1227

Dorrance AE, McClure SA, Martin SKS (2003) Effect of partial resistance on Phytophthora stem rot incidence and yield of soybean in Ohio. Plant Dis 87:308-312

Duan MJ, Sun ZZ, Shu LP, Tan YN, Yu D, Sun XW, Liu RF, Li YJ, Gong SY, Yuan DY (2013) Genetic analysis of an elite superhybrid rice parent using high-density SNP markers. Rice 6:21

Fan AY, Wang XM, Fang XP, Wu XF, Zhu ZD (2009) Molecular identification of Phytophthora resistance gene in soybean cultivar Yudou 25. Acta Agron Sin 35: 1844-1850

Gao HY, Bhattacharyya MK (2008) The soybean-Phytophthora resistance locus Rpsl-k encompasses coiled coil-nucleotide binding-leucine rich repeat-like genes and repetitive sequences. BMC Plant Biol 8:29

Gao HY, Narayanan NN, Ellison L, Bhattacharyya MK (2005) Two classes of highly similar coiled coil-nucleotide binding-leucine rich repeat genes isolated from the Rpsl-k locus encode Phytophthora resistance in soybean. Mol Plant Microbe Interact 18:1035-1045

Gordon SG, Martin SKS, Dorrance AE (2006) Rps8 maps to a resistance gene rich region on soybean molecular linkage group $\mathrm{F}$. Crop Sci 46:168-173

Han YP, Teng WL, Yu KF, Poysa V, Anderson T, Qiu LJ, Lightfoot DA, Li WB (2008) Mapping QTL tolerance to Phytophthora root rot in soybean using microsatellite and RAPD/SCAR derived markers. Euphytica 162:231-239

Hartwig EE, Keeling BL, Edwards CJ (1968) Inheritance of reaction to Phytophthora rot in the soybean. Crop Sci 8:634-636

Huang XH, Feng Q, Qian Q, Zhao Q, Wang L, Wang AH, Guan JP, Fan DL, Weng QJ, Huang T, Dong GJ, Sang T, Han B (2009) 
High-throughput genotyping by whole-genome resequencing. Genome Res 19:1068-1076

Huang J, Guo N, Li YH, Sun JT, Hu GJ, Zhang HP, Li YF, Zhang X, Zhao JM, Xing H, Qiu LJ (2016) Phenotypic evaluation and genetic dissection of resistance to Phytophthora sojae in the Chinese soybean mini core collection. BMC Genet 17:85

Hyten DL, Song QJ, Choi IY, Yoon MS, Specht JE, Matukumalli LK, Nelson RL, Shoemaker RC, Young ND, Cregan PB (2008) Highthroughput genotyping with the GoldenGate assay in the complex genome of soybean. Theor Appl Genet 116(7):945-952

Hyten DL, Choi IY, Song QJ, Specht JE, Carter TE, Shoemaker RC, Hwang EY, Matukumalli LK, Cregan PB (2010) A high density integrated genetic linkage map of soybean and the development of a 1536 universal soy linkage panel for quantitative trait locus mapping. Crop Sci 50(3):960-968

Jia HY, Kurle JE (2008) Resistance and partial resistance to Phytophthora sojae in early maturity group soybean plant introductions. Euphytica 159:27-34

Kotera E, Tasaka M, Shikanai T (2005) A pentatricopeptide repeat protein is essential for RNA editing in chloroplasts. Nature 433(7023):326-330

Kyle DE, Nickell CD, Nelson RL, Pedersen WL (1998) Response of soybean accessions from provinces in southern China to Phytophthora sojae. Plant Dis 82(5):555-559

Lee S, Mian MAR, McHale LK, Wang H, Wijeratne AJ, Sneller CH, Dorrance AE (2013a) Novel quantitative trait loci for partial resistance to Phytophthora sojae in soybean PI 398841. Theor Appl Genet 126:1121-1132

Lee S, Rouf Mian MA, McHale LK, Sneller CH, Dorrance AE (2013b) Identification of quantitative trait loci conditioning partial resistance to in soybean PI 407861 A. Crop Sci 53:1022

Lee S, Mian MAR, Sneller CH, Wang H, Dorrance AE, McHale LK (2014) Joint linkage QTL analyses for partial resistance to Phytophthora sojae in soybean using six nested inbred populations with heterogeneous conditions. Theor Appl Genet 127:429-444

Li BY, Ma SM (1999) The occurrence of soybean Phytophthora root rot and its control. Chin J Oil Crop Sci 21:47-50

Li R, Yu C, Li Y, Lam TW, Yiu SM, Kristiansen K, Wang J (2009a) SOAP2: an improved ultrafast tool for short read alignment. Bioinformatics 25:1966-1967

Li H, Handsaker B, Wysoker A, Fennell T, Ruan J, Homer N, Marth G, Abecasis G, Durbin R (2009b) The sequence alignment/map format and SAMtools. Bioinformatics 25:2078-2079

Li XP, Han YP, Teng WL, Zhang SZ, Yu KF, Poysa V, Anderson T, Ding JJ, Li WB (2010) Pyramided QTL underlying tolerance to Phytophthora root rot in mega-environments from soybean cultivars 'Conrad' and 'Hefeng 25'. Theor Appl Genet 121:651-658

Li B, Tian L, Zhang JY, Huang L, Han FX, Yan SR, Wang LZ, Zheng HK, Sun JM (2014) Construction of a high-density genetic map based on large-scale markers developed by specific length amplified fragment sequencing (SLAF-seq) and its application to QTL analysis for isoflavone content in Glycine max. BMC Genom 15:1086. doi:10.1186/1471-2164-15-1086

Lin F, Zhao MX, Ping JQ, Johnson A, Zhang B, Abney TS, Hughes TJ, Ma JX (2013) Molecular mapping of two genes conferring resistance to Phytophthora sojae in a soybean landrace PI 567139B. Theor Appl Genet 126:2177-2185

Lin F, Zhao MX, Baumann DD, Ping JQ, Sun LJ, Liu YF, Zhang B, Tang ZX, Hughes E, Doerge RW, Hughes TJ, Ma JX (2014) Molecular response to the pathogen Phytophthora sojae among ten soybean near isogenic lines revealed by comparative transcriptomics. BMC Genomics 15:18

Lohnes DG, Nickell CD, Schmitthenner AF (1996) Origin of soybean alleles for Phytophthora resistance in China. Crop Sci 36:1689-1692
Michelmore RW, Paran I, Kesseli RV (1991) Identification of markers linked to disease-resistance genes by bulked segregant analysis: a rapid method to detect markers in specific genomic regions by using segregating populations. Proc Natl Acad Sci USA 88:9828-9832

Mueller EH, Athow KL, Laviolette FA (1978) Inheritance of resistance to four physiologic races of Phytophthora megasperma var sojae. Phytopathology 68:1318-1322

Nguyen VT, Vuong TD, VanToai T, Lee JD, Wu X, Rouf Mian MA, Dorrance AE, Shannon JG, Nguyen HT (2012) Mapping of QTL associated with resistance to Phytophthora sojae and flooding tolerance in soybean. Crop Sci 52:2481-2493

Ping JQ, Fitzgerald JC, Zhang CB, Lin F, Bai YH, Wang DC, Aggarwal R, Rehman M, Crasta O, Ma JX (2016) Identification and molecular mapping of Rps11, a novel gene conferring resistance to Phytophthora sojae in soybean. Theor Appl Genet 129:445-451

Polzin KM, Lohnes DG, Nichell CD, Shoemaker RC (1994) Integration of Rps2, Rmd, and Rj2 into linkage group $\mathrm{J}$ of the soybean molecular map. J Hered 85(4):300-303

Qi XP, Li MW, Xie M, Liu X, Ni M, Shao GH, Song C, Yim AKY, Tao Y, Wong FL, Isobe S, Wong CF, Wong KS, Xu CY, Li CQ, Wang Y, Guan R, Sun FM, Fan GY, Xiao ZX, Zhou F, Phang TH, Liu X, Tong SW, Chan TF, Yiu SM, Tabata S, Wang J, Xu X, Lam HM (2014) Identification of a novel salt tolerance gene in wild soybean by whole-genome sequencing. Nat Commun 5:4340. doi:10.1038/ncomms5340

Ren HL, Ma QB, Yang CY, Song EL, Wang RP, Ma TX, Tang YJ, Nian H (2012) Screening soybean germplasms resistant to Phytophthora sojae in South China. Soybean Sci 31(3): 453-456

Sandhu D, Gao HY, Cianzio S, Bhattacharyya MK (2004) Deletion of a disease resistance nucleotide-binding-site leucine-rich-repeatlike sequence is associated with the loss of the Phytophthora resistance gene Rps4 in soybean. Genetics 168:2157-2167

Sandhu D, Schallock KG, Rivera-Velez N, Lundeen P, Cianzio S, Bhattacharyya MK (2005) Soybean phytophthora resistance gene Rps 8 maps closely to the Rps3 region. J Hered 96:536-541

Schmitthenner AF (1985) Problems and progress in control of Phytophthora root rot of soybean. Plant Dis 69:362-368

Schmitthenner AF (1999) Phytophthora rot of soybean. In: Hartman GL, Sinclair JB, Rupe JC (eds) Compendium of soybean diseases, 4th edn. The American Phytopathological Society. (APS) Press, St Paul, pp 39-42

Schneider R, Rolling W, Song Q, Cregan P, Dorrance AE, McHale LK (2016) Genome-wide association mapping of partial resistance to Phytophthora sojae in soybean plant introductions from the Republic of Korea. BMC Genom 17: 607

Shen CY, Su YC (1991) Discovery and preliminary studies of Phytophthora megasperma on soybean in China. Acta Phytopathol Sin 21: 298

Song QJ, Jia GF, Zhu YL, Grant D, Nelson RT, Hwang EY, Hyten DL, Cregan PB (2010) Abundance of SSR motifs and development of candidate polymorphic SSR markers (BARCSOYSSR_1.0) in soybean. Crop Sci 50:1950-1960

Sugimoto T, Yoshida S, K W, Aino M, Kanto T, Maekawa K (2008) Identification of SSR markers linked to the Phytophthora resistance gene Rps1-d in soybean. Plant Breed 127:154-159

Sugimoto T, Yoshida S, Kaga A, Hajika M, Watanabe K, Aino M, Tatsuda K, Yamamoto R, Matoh T, Walker DR (2011) Genetic analysis and identification of DNA markers linked to a novel Phytophthora sojae resistance gene in the Japanese soybean cultivar Waseshiroge. Euphytica 182:133-145

Sugimoto T, Kato M, Yoshida S, Matsumoto I, Kobayashi T, Kaga A, Hajika M, Yamamoto R, Watanabe K, Aino M, Matoh T, Walker DR, Biggs AR, Ishimoto M (2012) Pathogenic diversity 
of Phytophthora sojae and breeding strategies to develop Phytophthora-resistant soybeans. Breeding. Science 61:511-522

Sun S, Zhao JM, Wu XL, Guo N, Wang YC, Gai JY, Xing H (2008) Resistance of soybean germplasm to Phytophthora in Huanghuai valley. Soybean Sci 27(3):465-470

Sun S, Wu XL, Zhao JM, Wang YC, Tang QH, Yu DY, Gai JY, Xing H (2011) Characterization and mapping of RpsYu25, a novel resistance gene to Phytophthora sojae. Plant Breed 130:139-143

Sun JT, Li LH, Zhao JM, Huang J, Yan Q, Xing H, Guo N (2014a) Genetic analysis and fine mapping of RpsJS, a novel resistance gene to Phytophthora sojae in soybean [Glycine $\max (\mathrm{L}$.) Merr]. Theor Appl Genet 127:913-919

Sun J, Guo N, Lei J, Li L, Hu G, Xing H (2014b) Association mapping for partial resistance to Phytophthora sojae in soybean (Glycine $\max$ (L.) Merr.). J Genet 93:355-363

Tang QH, Cui LK, Li DL, Dai TT, Yin WX, Dong SM, Xing H, Zheng XB, Wang YC (2010) Resistance evaluation of soybean germplasm from Huanghuai Valley to Phytophthora root rot. Sci Agric Sin 43(11): 2246-2252

Tucker DM, Saghai Maroof MA, Mideros S, Skoneczka JA, Nabati DA, Buss GR, Hoeschele I, Tyler BM, Martin SKST, Dorrance AE (2010) Mapping quantitative trait loci for partial resistance to Phytophthora sojae in a soybean interspecific cross. Crop Sci 50:628-635

Tyler BM (2007) Phytophthora sojae: root rot pathogen of soybean and model oomycete. Mol Plant Pathol 8(1):1-8

Voorrips RE (2002) MapChart: software for the graphical presentation of linkage maps and QTLs. J Heredity 93(1):77-78

Wang HH, Waller LC, Tripathy S, Martin SKS, Zhou LC, Krampis K, Tucker DM, Mao YC, Hoeschele I, Maroof MAS, Tyler BM, Dorrance AE (2010) Analysis of genes underlying soybean quantitative trait loci conferring partial resistance to Phytophthora sojae. Plant Genome 3:23-40

Wang L, Wang AH, Huang XH, Zhao Q, Dong GJ, Qian Q, Sang T, Han B (2011) Mapping 49 quantitative trait loci at high resolution through sequencing-based genotyping of rice recombinant inbred lines. Theor Appl Genet 122:327-340

Wang H, St. Martin SK, Dorrance AE (2012a) Comparison of phenotypic methods and yield contributions of quantitative trait loci for partial resistance to in soybean. Crop Sci 52(2):609-622

Wang H, Wijeratne A, Wijeratne S, Lee S, Taylor CG, St MS, McHale L, Dorrance AE (2012b) Dissection of two soybean QTL conferring partial resistance to Phytophthora sojae through sequence and gene expression analysis. BMC Genom 13:428

Wang LH, Xia QJ, Zhang YX, Zhu SD, Zhu XF, Li DH, Ni XM, Gao Y, Xiang HT, Wei X, Yu JY, Quan ZW, Zhang XR (2016) Updated sesame genome assembly and fine mapping of plant height and seed coat color QTLs using a new high-density genetic map. BMC Genomics 17:31

Weng C, Yu K, Anderson TR, Poysa V (2001) Mapping genes conferring resistance to Phytophthora root rot of soybean, Rpsla and Rps7. J Hered 92(5):442-446

Weng CR, Yu KF, Anderson TR, Poysa V (2007) A quantitative trait locus influencing tolerance to Phytophthora root rot in the soybean cultivar 'Conrad'. Euphytica 158:81-86

Wrather JA, Anderson TR, Arsyad DM, Tan Y, Ploper LD, PortaPuglia A, Ram HH, Yorinori JT (2001) Soybean disease loss estimates for the top 10 soybean-producing countries in 1998. Can J Plant Pathol 23:115-121

Wu XL, Zhang BQ, Sun S, Zhao JM, Yang F, Guo N, Gai JY, Xing $\mathrm{H}$ (2011a) Identification, genetic analysis and mapping of resistance to Phytophthora sojae of Pm28 in soybean. Agric Sci China 10(10): 1506-1511

Wu XL, Zhou B, Sun S, Zhao JM, Chen SY, Gai JY, Xing H (2011b) Genetic analysis and mapping of resistance to Phytophthora sojae of Pm14 in soybean. Sci Agric Sin 44(3): 456-460

Wu XL, Zhou B, Zhao J, Guo N, Zhang B, Yang F, Chen S, Gai J, Xing H (2011c) Identification of quantitative trait loci for partial resistance to Phytophthora sojae in soybean. Plant Breed 130:144-149

Xia CJ, Zhang JQ, Wang XM, Wu XF, Liu ZX, Zhu ZD (2011) Analyses of resistance genes to Phytophthora root rot in soybean germplasm. Chin J Oil Crop Sci 33(4):396-401

Yao HY, Wang XM, Wu XF, Xiao YN, Zhu ZD (2010) Molecular mapping of Phytophthora resistance gene in soybean cultivar Zaoshu 18. J Plant Genet Resour 11(2):213-217

Yu AL, Xu PF, Wang JS, Zhang SZ, Wu JJ, Li WB, Chen WY, Li NH, Fan SJ, Wang X, Jiang LY (2010) Genetic analysis and SSR mapping of gene resistance to Phytophthora sojae race 1 in soybean cv Suinong 10. Chin J Oil Crop Sci 32(4):462-466

Zeng ZB (1993) Theoretical basis for separation of multiple linked gene effects in mapping quantitative trait loci. Proc Natl Acad Sci USA 90:10972-10976

Zeng ZB (1994) Precision mapping of quantitative trait loci. Genetics 136:1457-1468

Zhang SZ, Xu PF, Wu JJ, Xue AG, Zhang JX (2010) Races of Phytophthora sojae and their virulences on soybean cultivars in Heilongjiang, China. Plant Dis 94:87-91

Zhang JQ, Xia CJ, Duan CX, Sun SL, Wang XM, Wu XF, Zhu ZD (2013a) Identification and candidate gene analysis of a novel Phytophthora resistance gene Rps10 in a Chinese soybean cultivar. PLoS One 8(7):e69799

Zhang JQ, Xia CJ, Wang XM, Duan CX, Sun SL, Wu XF, Zhu ZD (2013b) Genetic characterization and fine mapping of the novel Phytophthora resistance gene in a Chinese soybean cultivar. Theor Appl Genet 126:1555-1561

Zhang JQ, Xia CJ, Duan CX, Sun SL, Wang XM, Wu XF, Zhu ZD (2013c) Identification and candidate gene analysis of a novel Phytophthora resistance gene Rps10 in Chinese soybean cultivar. Plos One 8(7):1-8

Zhang ZN, Hao JJ, Yuan JZ, Song QJ, Hyten DL, Cregan PB, Zhang GR, Gu CH, Li M, Wang DC (2014) Phytophthora root rot resistance in soyean E00003. Crop Sci 54:492-499

Zhu ZD, Wang HB, Wang XM, Chang RZ, Wu XF (2004) Distribution and virulence diversity of Phytophthora sojae in China. Agric Sci China 3(2): 116-123

Zhu ZD, Huo YL, Wang XM, Huang JB, Wu XF (2006) Screening for resistance sources to Phytophthora root rot in soybean. J Plant Genet Resour 7(1):24-30

Zhu ZD, Huo YL, Wang XM, Huang JB, Wu XF (2007) Molecular identification of a novel Phytophthora resistance gene in soybean. Acta Agron Sin 33(1): 154-157 